\title{
Capitalism in the pastoral mode and Hardy's Far from the Madding Crowd
}

\section{Ayşe Çelikkol}

To cite this article: Ayșe Çelikkol (2020) Capitalism in the pastoral mode and Hardy's Far from the Madding Crowd, Nineteenth-Century Contexts, 42:5, 523-536, DOI: 10.1080/08905495.2020.1816084

To link to this article: https://doi.org/10.1080/08905495.2020.1816084

曲 Published online: 05 Jan 2021.

Submit your article to this journal $\widetilde{T}$

Џll Article views: 227

Q View related articles $\llbracket$

View Crossmark data $\nearrow$ 


\title{
Capitalism in the pastoral mode and Hardy's Far from the Madding Crowd
}

\author{
Ayşe Çelikkol
}

Department of English Language and Literature, Bilkent University, Ankara, Turkey

Horace's second epode features a rich usurer named Alfius who imagines the pleasures of rural life. In his account, the country provides a haven from financial circuits of credit and interest, however labor-intensive the farmer's life may be:

Happy the man, who far from town affairs,

The life of old-world mortals shares;

With his own oxen tills his forebears' fields,

Nor thinks of usury and its yields. $(1907,245)$

Alfius attributes timelessness to his imagined Arcadia, which offers a retreat from the city. ${ }^{1}$ As Virgil's Eclogues (2012) demonstrates, the pastoral can represent rural economic plights such as dispossession, ${ }^{2}$ but Alfius in his pastoral moment idealizes the country.

When capitalism conquers town and country alike, what happens to the pastoral's reputed distance from "usury and its yields"? How can the pastoral mode communicate the distinctness of rural experience if, at the same time, it acknowledges the presence of capitalist relations in the country? This essay turns to a version of the pastoral that locates country life within capitalist networks of production and exchange: in Thomas Hardy's Far from the Madding Crowd (1874), the narrator depicts wage-labor, addresses leases and debts, and treats exchange relations as ubiquitous. Capitalist relations are not external to the characters' dealings with the crops and the sheep, but inextricable from them. The sheep are bought on credit; the wheat and barley are for the marketplace. When the pastoral is attentive to economic forces, it displays the historicity of the natural world, revealing, for example, the ways in which finance shapes the lives of nonhuman animals.

Writing to Leslie Stephen about his plans for Far from the Madding Crowd, Hardy identified it as "a pastoral tale" (Hardy 1962, 95). Within the novel, the designation persists. The narrator calls Gabriel Oak, at that point a tenant farmer, a "pastoral king" and describes the death of his sheep as a "pastoral tragedy" (Hardy 2002, 38). The pastoral indeed presents a useful paradigm for approaching the characters and the plot: the sheep, the corn, and the characters' dealings with them structure the flow of time, shape courtship rituals, and even mold subjectivity in the novel. Shearing and harvest rituals punctuate the plot; Gabriel and Bathsheba connect as they protect the wheat and 
barley from the rain; Boldwood is declared insane because he wastes his harvest. Even though the contours of rural life are shaped by capitalism, they remain distinct from their urban counterpart.

These rural practices exist in the same context as market-driven transactions and wage labor, with capitalist relations deeply embedded in the nonhuman world. Hardy's approach to the countryside resonates with the view that the political theorist Ellen Meiksins Wood ascribes to Marx, namely that the "system of relations between landlords, tenants, and wage-laborers in which the landlords... increasingly derived their rent from the profits of capitalist tenants" produced "the real "primitive accumulation" $(2008,87)$. Transactions by merchants and industrialists alone do not account for capitalist development. As Paul Burkett highlights, Marx asserted "'surplus value rests on a natural basis'” (Marx 1967, 511; qtd. in Burkett 2003, 150). Marx admired the physiocrats' treatment of the landowner as a capitalist, though he criticized their inability to recognize that surplus labor gave rise to profits (Marx 1975, 51-52). If Hardy's fiction thematizes the insight that rural space is not exempt from the imperatives of capitalism, it counters the presumed separation of nature and culture.

Critics have recently noted the inseparability of nature and culture in Hardy's fiction, especially in Tess of the D'Urbervilles (1891). Focusing on that novel, Jessica Martell writes, "Hardy's natural world can be entwined in, and inextricable from, the human world of social labor" $(2013,72)$. Nathan Hensley and Philip Steer, also analyzing Tess, assert that "The dairy in the Vale of Froom ... begins to appear as inextricably linked to, and therefore a product of, the very carbon modernity the novel conscripts it to symbolically contrast" $(2018,7)$. In a similar vein, Ivan Kreilkamp asserts that in Far from the Madding Crowd, the "natural' or nonhuman world" is "fully embedded into and inextricable from the human and social world" $(2009,474)$. Yet what has not received much attention in critical treatments of this novel is the centrality of capitalist practices to those social ties that extend into the nonhuman world. As Hardy lays bare, wage labor, debt, competition, and other elements of capitalism shape the human relation to nonhuman animals and the land while also presenting a vocabulary for the evaluation of human nature. I argue that Far from the Madding Crowd historicizes the natural world not in spite of its pastoral qualities, but because of them. In portraying human connections to nonhuman lives and the landscape as the pastoral tends to do, Hardy invites history into the mix. The suffusion of the natural world with capitalism in the novel has much to reveal about Hardy's adaptation of the pastoral: acknowledging the historical making of rural life, he establishes continuity with those versions of the pastoral that depict the politics of landownership and labor, from Virgil's Eclogues to William Wordsworth's "Michael: A Pastoral Poem" (1800). These works' portrayals of eviction and debt similarly revolve around the human relation to the land.

At stake in the entanglement of the pastoral and the economic is a view of organic matter and non-human living beings as implicated in social relations of production and exchange. "Nature is, above all, historical," writes the environmental historian Jason Moore $(2015,19)$. Under capitalism, the historicity of nature implies a set of symmetrical claims: "capitalism makes nature" and "nature makes capitalism" (18). The first of these two claims refers to the ways in which humans make environments, and the second attests to the role that the natural world plays in shaping economic structures. As Moore elaborates, human and nonhuman actors together create environments, so to 
assert that nature makes capitalism is to recognize the input of human and nonhuman entities. In this sense, capitalism is co-produced. For instance, forests have been put to work in the rise of capitalism, and so has exploited human labor. Conversely, historical natures are themselves products of capitalism, as twentieth- and twenty-first century examples such as IVF and GMO attest. The notion of historical natures offers a corrective to Nature spelled with a capital "n":

Capitalism is not a structurally invariant, monolithic Society, acting upon a structurally invariant, external Nature. Rather, the history of capitalism is one of successive historical natures, which are both producers and products of capitalist development. (19)

In the age of capital, market-oriented production and the law of value shape historical nature.

Far from the Madding Crowd turns to the material production of nature most directly when the narrator describes the blending of the sheep:

Oak took from his illimitable pockets a marking iron, dipped it into the pot, and imprinted on the buttocks of the infant sheep the initials of her he delighted to muse on-"B. E.," which signified to all the region round that henceforth the lambs belonged to Farmer Bathsheba Everdene, and to no one else. (113)

The sheep are private property, and that status is inscribed in their flesh. Even as symbolic a realm as language ("B. E.") merges with nonhuman materiality through the act of imprinting. Ownership is confirmed at the moment the body comes to bear the initials, not sooner.

The mark of capitalism on farming in Far from the Madding Crowd is perhaps most evident in the depiction of the Casterbridge "hiring fair" and the account of wage labor on Bathsheba's farm (43). The latter becomes explicit when Bathsheba, having just dismissed her bailiff, decides to "manage everything with her own head and hands" (79). It is a single moment that evinces both the commodification of labor and the rural innocence that characterizes the pastoral. Making plans to manage the farm, Bathsheba asks,

"Now the next. Laban Tall, you'll stay on working for me?"

"For you or anybody that pays me well, ma'am," replied the young married man. (81)

Labor is a commodity that the laborer puts on the market. The comment positions Laban Tall as an earnest man, and it also shows that he lacks any deep attachment to a master.

Wage-labor as well as market-oriented production, which the historian Leigh ShawTaylor singles out as the two dominant characteristics of capitalist farming $(2011,31)$, mark rural life in Far from the Madding Crowd. In a reading of Tess of the D'Urbervilles, Arnold Kettle emphasizes the same two developments to discuss "the destruction of the peasantry" in that novel $(2016,45)$ :

With the extension of capitalist farming (farming, that is to say, in which the landowner farms not for subsistence but for profit and in which the land-workers become wage earners) the old yeoman class of small holders or peasants, with their traditions of independence and their own native culture was bound to disappear. (45)

Kettle captures the transformation in farming that Hardy's fiction depicts. In addition to wage-labor and market-oriented production, wealth in this setting obeys capitalist dictates 
(Goode 1990, 28). Ralph Pite's (2009) assertion that "no one and nothing is insulated from the modern" in Hardy's fiction governs the situation in Weatherbury (141), whose residents, to use Adam Smith's words, “truck, barter, and exchange" $(1887,7)$.

The ironies produced by the historicity of nature energize this rendition of the pastoral. It is perhaps a meta-level commentary that the novel positions the realm of the aesthetic as animated by exchange value. The narrator approaches the sheep from an aesthetic perspective at the very moment their coat is prepared for exchange. Beauty surfaces most fully in a profit-driven moment. It is shearing, the process of producing exchange value out of organic matter, that brings out the most beautiful aspect of the sheep:

The clean, sleek creature arose from its fleece-how perfectly like Aphrodite rising from the foam should have been seen to be realized-looking startled and shy at the loss of its garment which lay on the floor in one soft cloud, united throughout, the portion visible being the inner surface only, which, never before exposed, was white as snow. (145-146)

The peculiar, and perhaps ironic, Aphrodite simile deifies the animals at the moment they become producers of exchange value. The English pastoral counterpart to Greek mythology replaces the sea imagery with that of fleece, ascribing a sublime quality to organic matter. Paradoxically, the point that is most economic is also the one where we seem to get unmediated access to nature, in the form of the pure white hiding under the darker shades of fleece. What we appreciate for its purity is disclosed on the way to the market.

\section{Economic affairs in the pastoral mode}

Recent literary criticism has acknowledged the resonance of capitalism with Hardy's use of the pastoral. ${ }^{3}$ Indy Clark, who analyzes labor and class in Hardy's poetry, writes that "by making visible the relations of capitalism, Hardy's pastoral diverges from what was seen as that mode's traditional path" $(2015,186)$. Similarly, analyzing Tess, Jessica Martell reads "Hardy's pastoral as an important measure of the uneven integration of rural communities into industrial modernity" specifically as she addresses the capitalist tendency for "overproduction up and down the supply lines" (2013, 67, 82). Far from the Madding Crowd remains alert to historical forces - to the maturing of capitalism in the agrarian world by highlighting the exchange value attached to the crops and the sheep, and by locating labor, in its human and nonhuman varieties, in circuits shaped by the accumulation of capital.

Hardy is not the only nineteenth-century pastoralist to complicate the pastoral by integrating modern developments into the rural fabric. Leo Marx argues that US fiction, poetry, and non-fiction prose of the past centuries spared a "place for the machine in the myth of the garden" and incorporated the economic and technological developments associated with modernity into the pastoral $(1964,182)$. Trains, for instance, harmonized with traditionally pastoral scenes: in "the industrialized version of the pastoral ideal," "the railroad is the chosen vehicle for bringing America into its own pastoral utopia" (222, 225). It is possible to extend Marx's argument beyond the US. In Britain, Harriet Martineau celebrated the colonies as pastoral homes to nascent capitalist development in her Illustrations of Political Economy (1832-1834) (Çelikkol 2020). In Hardy's work capitalism is far from idealized, but his pastoral, like that of Martineau, represents and evaluates economic practices. 
Characteristics inherent to the pastoral explain its ability to capture the flow of history - an ability that remains dormant in some varieties of the pastoral. "The desirability of a ... reconciliation between the animal and rational, natural and civilized conditions of man always had been implied by the pastoral ideal," writes Leo Marx (102). Situated between polar terms, the pastoral offers a "symbolic middle landscape" (71). As these characteristics suggest, the mode does not revolve around a presumably pure Nature that excludes the human. Within Far from the Madding Crowd, sheep-shearing offers that middle landscape and exemplifies the immersion of nonhuman lives within relations of production. So do the sheep being imprinted with Bathsheba's initials. Especially in the portrayal of shepherding but also in that of agriculture, Hardy seizes a capacity inherent in the mode to communicate the historicity of ecological forms and relations. This capacity often goes unnoticed in literary criticism that opposes the pastoral to realism or treats the historical contingency of the setting as anti-pastoral. Richard Nemesvari, for example, maintains that Far from the Madding Crowd "prepares its audience for a pastoral idyll but then juxtaposes this with the harsh materialism of agricultural economics" $(2007,102)$. Yet if we take the middle landscape rather than idealization as a key feature of the pastoral, then that mode's representation of agricultural economics is no contradiction.

In treating the modern pastoral as a mode that cannot accommodate the economic, Nemesvari indeed simplifies Raymond Williams's position. Williams recognizes that Hardy rejects a "seamless, abstracted country 'way of life" (1970, 113). "[S]ocial forces within his fiction are deeply based on the rural economy itself" and on "actual relationships between people, which occur within existing contemporary pressures" (113-114). Attentive to "the harshness of economic processes," his novels treat "the social process" as "one of class and separation, as well as chronic insecurity, as this capitalist farming and dealing takes its course" (115). Yet for Williams, Hardy's portrayal of a complex, ever-changing economic world distances him from the pastoral: "the profound disturbances that Hardy records cannot ... be seen in the sentimental terms of a pastoral: the contrast between the country and town" (115). The limits Williams assigns to the pastoral here contrast his discussion of the centrality of economic relations in Virgil's Eclogues. Advocating a less circumscriptive understanding of the mode in order to attend to the historicity of the natural world, I suggest that the modern pastoral can portray agrarian capitalism while maintaining a distinction between country and town.

Even when read through the lens of capitalism, the difference between the country and the town persists in the pastoral. Consider the operation of time. Under capitalism, "abstract" time, based on uniform clock intervals, emerges in counter distinction to its pre-capitalist "concrete" alternative, the latter being dependent on natural phenomena (Harootunian et al. 2012, 9). ${ }^{4}$ The imperatives of capital accumulation organize Gabriel's, Bathsheba's, and others' lives, but the temporality they experience still depends on the flow of seasons. The concreteness of time in this novel is not just a nostalgic throwback to premodernity, though it is also that. Ever adaptive, capitalism in this case extracts surplus labor out of an enclave operating in seasonal time. Capitalism does not homogenize its settings. Thus, the "contrast between country and town" is not a "sentimental" evocation of the pre-modern, but a reflection of agrarian capitalism's coexistence with, and distinction from, its industrial and financial variants in the nineteenth century. The pastoral persists in modernity based on that distinction. 
Hardy's fiction showcases the resonance of the modern pastoral with realism. Hardy was able to combine pastoral elements with realist principles seamlessly in his work in part because of the influence of the economic in both. Far from the Madding Crowd conforms to realism insofar as it privileges the local and the everyday and inspires the feeling that its farmers correspond to real-life counterparts. Bathsheba's farm seems typical in its economic structure: historically, "by 1800, while many small farmers survived, England had a unique rural structure of landlords leasing farms to tenants who employed landless wage labourers" (Bryer 2004, 1). In addition, typical of Hardy's realist experiment, the novel traces "ordinary individuals' responses to extraordinary circumstances" (O'Gorman 2013, 116). This kind of realism is not at odds with the pastoral, which also characteristically revolves around a representative figure (Alpers 2011, 26). Further, taking place in that "middle landscape" between the human-made environments and nonhuman lives, the pastoral at times pays attention to production and exchange involved in herding. To capture the metabolic interaction between humans and their environments as the pastoral can is to consider the economic. Similarly, economic affairs from money lending to bankruptcy are among the preoccupations of realism as they help to inquire into the nature of representation and to address questions of community and its fragmentation. Realism and the pastoral thus converge though their mutual tendency to portray economic activities.

\section{Historical forces and the trajectory of the pastoral}

Idealized representations expel traces of historical materiality, and some versions of the pastoral are products of such abstraction. Yet not all pastorals abstract, and Hardy indeed taps into a rich tradition by historicizing rural experiences that remain distinct from their urban counterparts. This section suggests that historicization is an affordance of the pastoral, ${ }^{5}$ though one that remains dormant in some renditions of it, such as neoclassical ones. Hardy, like Wordsworth before him, seizes on this affordance.

The traditional opposition between the court and the shepherd's life would suggest that the countryside exists in isolation from economic tensions or political developments. Herbert Lindenberger considers a crucial moment in the third of Shakespeare's Henry VI plays, in which the king contemplates taking on a shepherd's life. By abandoning courtly life, he would manage to leave behind "Care, Mistrust, and Treason" (2.5.54; qtd. in Lindenberger 1972, 336):

O God methinks it were a happy life

To be no better than a homely swain;

To sit upon a hill, as I do now,

To carve out dials quaintly, point by point,

Thereby to see the minutes how they run. (2.5.21-25; qtd. in Lindenberger 1972, 335)

In this model, pastoral temporality, an entity onto its own, is isolated from the flow of history. The pastoral in this instance offers "relief" from "the bitter realities of the historical world" and "seems to transcend the limitations of the historical world" (336). Yet, as Peter Lindenbaum notes, it is not always possible to extract history from the pastoral in 
Shakespeare's plays. Based on this consideration, Lindenbaum arrives at a dialectical understanding of the pastoral, in which the mode always places an ahistorical temporality in relation to historical forces. For him, historical elements constitute the anti-pastoral within the pastoral. Sidney, Shakespeare, and Milton, "returning to the conception of pastoral shared by Theocritus and Virgil," used the pastoral not to "express nostalgia for a better time and better place," but to take advantage of the "pastoral's ability to picture our present life in small" $(1986,21)$. My argument similarly posits the difficulty of keeping history at bay when it comes to the pastoral, though, unlike Lindenbaum, I do not call these elements "anti-pastoral." If such elements are so often an integral part of the pastoral, that designation appears misleading. In certain strands of the pastoral, history coexists with the timeless, however strongly the two may be in tension.

The distinction between "hard" and "soft" pastoral (Lindenberger 1972, 338), with the latter denoting an idealized form and the former implying an attention to the vicissitudes of life in the countryside, is useful in tracing the incorporation of history into the pastoral. Hard pastoral, which resists stock depictions of locus amoenus, persists through the centuries and attends to the historical elements of rural life. Puttenham wrote that the goal of the pastoral was "to insinuate and glaunce at greater matters" $(1869,53)$. Recent literary criticism has explored precisely how these "greater matters" mold the pastoral and inform its content. Paul Alpers writes that Virgil "extended the pastoral to engage social and political realities that were excluded by Theocritus" (2011, 161). Annabel Patterson similarly turns to the proliferation of political issues in Virgil's Eclogues, from patronage and landownership to personal liberty. For Isabel MacCaffrey, Spenser's The Shepheardes Calender (1579), as allegory, revolves around the relation of "the nature of human life" to "the one life outside ... it" $(1969,91)$. The potential for historicity within the pastoral is perhaps stronger in the Romantic period. Jonathan Bate argues that Wordsworth's The Prelude (1850) "divests the pastoral of its ... myths of the golden age" (2013, 23): Wordsworth writes "a history of working people and local communities. To aggrandize the common man, to write the shepherd into history in this way is a radical move" (31). What Annabel Patterson calls Wordsworth's hard pastoral is in this sense an important precursor to Hardy's pastoral realism, in which historically contingent aspects of rural life blend with its timeless rhythms. When Hardy's pastoral portrays economic ties, it goes farther than Wordsworth's version in that it considers the implications of exchange value, utility, and wage-labor, thus charting out a role for the pastoral in an age where agrarian affairs were decidedly capitalist.

Despite all these instances in which history informs the pastoral imagination, the mode has a reputation for existing apart from the historical world in part because some of its modern incarnations sought to strip the mode of its material moorings. For Raymond Williams, the "living tensions are excised" from the "Renaissance adaptation of ... classical modes" (1975, 18). Annabel Patterson (1987) writes of the neoclassical pastoral's effacement of history: "What a neoclassical pastoral should imitate was neither Theocritus nor Virgil so much as an idea, necessarily nonexistent, 'of the simplicity and innocence of [the] Golden Age" (200). "To isolate the pastoral from major social and political issues" was a seventeenth- and eighteenth-century "program initiated by [René] Rapin and [Bernard le Bovier de] Fontenelle" (267). Perhaps reacting to this peculiar stage in the trajectory of the mode, Wordsworth's hard pastoral counters such abstraction, and Hardy's version does so as well. 


\section{The oscillation between the abstract and the concrete}

Abstraction is thematically relevant to Far from the Madding Crowd as well as playing a role in the history of the literary mode in which it is produced. The novel reflects on the history of the pastoral, which has oscillated between abstract and concretely historical representations of human interactions with the nonhuman. Hardy suggests that facile abstractions prove inadequate for understanding human experience. The attempt to purify fails, as we see in the case of Boldwood, who denies Bathsheba's status as homo economicus and misrecognizes the flesh-and-blood woman as an idealized entity. In the marketplace Farmer Boldwood cannot confront Bathsheba's role as economic agent even when a fit of jealousy requires him to accept that role:

His first impulse was to go and thrust himself between them [Bathesheba and a dashing young farmer] ... This could be done, but only in one way-by asking her to see a sample of her corn. Boldwood renounced the idea. He could not make the request; it was debasing loveliness to ask it to buy and sell, and jarred with his conceptions of her. (119)

Whereas Troy takes advantage of Bathsheba's status as an economic woman, Boldwood denies it. The narrator is alert to what Boldwood fails to recognize. Once Bathsheba inherits her uncle's possessions, we are told, she has "business in every bank in Casterbridge" (51). She participates in market day at the corn market in Casterbridge, the Corn Exchange. She is a "practical woman" who argues on prices and reduces them (90). Boldwood remains an outsider in that he cannot recognize the overlap between beauty and utility. His refusal to do so is part of a gendered ideology: "In contemplating Bathsheba as a woman, he had forgotten the accidents of her position as an agriculturist" (125). His imagination of womanhood resembles the conceptualization of a pure Nature, as both rely on subtracting history from what then becomes an idealized entity. In the rendition of the pastoral that Hardy offers in Far from the Madding Crowd, historical natures, like the woman farmer, resist the effort to purify and abstract.

The narrator is far from displaying Boldwood's urge to purify. Terms pertaining to the world of finance shed light on how human affect operates, which suggests that the implied reader is urban, as is usually the case in the pastoral tradition:

Love, being an extremely exacting usurer (a sense of exorbitant profit, spiritually, by an exchange of hearts, being at the bottom of pure passions, as that of exorbitant profit, bodily or materially, is at the bottom of those of lower atmosphere), every morning Oak's feelings were as sensitive as the money-market in calculations upon his chances. (29)

Even as the narrative voice exalts "pure passions" over financial ones, it privileges the latter as the source of a common language, under the assumption that the intended audience is familiar with, or located in, the world of finance. These metaphors of finance make it impossible to infer a free-floating human nature isolated from its surroundings.

Especially in its representation of financial dealings, Far from the Madding Crowd addresses the tension between the abstract and the concrete. The "pastoral tragedy," in which Gabriel Oak's younger dog leads the sheep to their deaths, sets up an interplay between the two terms. Things and living beings, in all their concreteness, also carry traces of exchange value, an abstract, commensurable entity. When the dog entices the sheep to jump to their deaths, Gabriel's initial reaction is grief for the loss of life: "His first feeling now was one of pity for the untimely fate of these gentle ewes and their 
unborn lambs" (41). The concern here is not for what the sheep could have fetched in the future, but for the actual moment, in which the bodies elicit a strong affective reaction. The second concern, on the other hand, involves the future. Insurance, or the lack thereof, raises the issue of the financial value of the sheep: "It was a second to remember another phase of the matter. The sheep were not insured" (41). Because Gabriel had gotten the sheep on credit ("an advance of sheep not yet paid for" [16]), he does not have the means to pay back his debt upon their death. As living beings, the sheep are valued for themselves, but also because their wool and flesh can, in the future, be converted into something else. The lives of the sheep are both concrete and abstract.

Just as building a fictional world seemingly devoid of economic dimensions involves abstraction, so can economistic thinking. Exchange value operates through abstraction. As Marx wrote, "In order to relate their products to one another as commodities, men are compelled to equate their various labors to abstract human labour. They do not know it, but they do it, by reducing the material thing to the abstraction, value" (1976, 36). Implicit in the act of exchange is an abstract unit of value that renders commodities commensurable. For this reason, abstractness characterizes any market-oriented exchange. Further, with the credit economy in place, capital is fictitious: "the category of fictitious capital is in fact implied whenever credit is extended in advance" (Harvey 1982, 266). Hardy's sheep, then, reflect the power of abstraction not only as carriers of exchange value, but as commodities in an economy of credit. At the same time, their incommensurable worth as living beings, so deeply felt by Gabriel, counters that abstraction. The carcasses remain after the exchange value evaporates.

Mathematical signs infiltrate the material world that Hardy's environmental imagination presents with unceasing attention to particularity. ${ }^{6}$ On the night Gabriel endeavors to save Bathsheba's crops from the storm, the abstract mathematical thinking is brought into focus through its contrast with the physical presence of those crops:

There were five wheat-ricks in this yard, and three stacks of barley. The wheat when threshed would average about thirty quarters to each stack; the barley, at least forty. Their value to Bathsheba, and indeed to anybody, Oak mentally estimated by the following simple calculation:-

$$
\begin{aligned}
& 5 \times 30=150 \text { quarters }=5001 . \\
& 3 \times 40=120 \text { quarters }=2501 .
\end{aligned}
$$

$$
\text { Total ... } 750 \text { 1. (240) }
$$

Gabriel's ease at performing the calculation suggests the extent to which such quantitative calculations are part of the life of agriculture. The concreteness of the wheat ricks and the stacks of barley intertwines with the mathematical abstraction involved in the numbers, the units, and the operations. Compressible and portable, exchange value coexists with the fullness of the ricks and stacks. "[F]ood for man and beast" is called "the divinest form that money can wear," which serves as a reminder that the crops are not for subsistence farming - they are vessels containing exchange value (240). Value is abstract, but its embodiments, distinct in their particularity, are the opposite. Money can "wear" divine form, but only when it is embodied rather than abstract. 
The close proximity of exchange and use value in the narrator's account contributes to the interplay of the abstract and the concrete that animates the novel. The sheep's coat will acquire use value only once it is exchanged: "three-and-a-half pounds of unadulterated warmth for the winter enjoyment of persons unknown and far away" (146). As Neil Smith notes, "with production for exchange, the relation with nature is no longer exclusively a use-value relation; use-values are not produced for direct use but for exchange" (1984, 40). Having become quantifiable in its concrete form, unadulterated warmth suggests an immediate presence, which stands in tension with the distance and the vagueness of the customers whose pleasures are deferred indefinitely. This kind of oscillation between the abstract and the concrete marks the novel's representations of animal and plant life. Attentive to the indirectness of exchange value while also stressing the immediacy implicit in experiences of farming, the modern pastoral here necessarily intertwines these two competing threads. Agricultural abstraction, familiar from the genre of political economy, becomes a constituent element of the modern pastoral, with the antithetical energy of the concrete also strongly marking the mode.

\section{Beyond capitalist temporality and relations}

While Far from the Madding Crowd acknowledges the presence of agrarian capitalism, its vision of productive activity is not limited to it. It gestures toward older modes of production as well as utopian ones whose potential is not fully realized. The archaic forms and rituals of farming are resilient in the novel. As Gillian Beer puts it, Hardy is "acutely alert to diverse time-scales" and our need to "inhabit" them all at once (234). The architecture of the "shearing-barn" betrays no change since its initial construction: "the old barn embodied practices which had suffered no mutilation at the hands of time" $(2000,136){ }^{7}$ Recognizing continuity across time is key to appreciating the architecture of the barn:

Here at least the spirit of the ancient builders was at one with the spirit of the modern beholder. Standing before this abraded pile, the eye regarded its present usage, the mind dwelt upon its past history, with a satisfied sense of functional continuity throughout-a feeling almost of gratitude, and quite of pride, at the permanence of the idea which had heaped it up. (143)

If the progressive flow of homogeneous empty time characterizes the temporality of capitalism, the barn conjures a deeper time, of course not so deep as to precede human existence, but deep enough to predate the rise of capitalism and the Anthropocene. Farming in this novel is an activity that simultaneously gestures toward the progressive and compressed temporality of capitalism and the deeper scale of the Holocene, the period that includes all of the recorded history of homo sapiens. As in the architecture of the barn, the shearing-supper conjures that deeper scale, as "the shearers reclined against each other as at suppers in the early ages of the world" (157). By asking us to register a double temporality, Hardy performs a task that twenty-first century ecological thought outlines: "The crisis of climate change calls for ... mix[ing] together the immiscible chronologies of capital and species history" (Chakrabarty 2009, 220). Such "immiscible chronologies" are what Far from the Madding Crowd combines. 
As the complex temporality of the barn suggests, Hardy's economic imagination does not always remain confined to capitalism. ${ }^{8}$ The novel explicitly names one alternative to capitalism. The merrymaking typical of Arcadia is associated with the collectivism of Saint Simonianism: “'Drink, Henry Fray - drink,' magnanimously said Jan Coggan, a person who held Saint-Simonian notions of share and share alike where liquor was concerned, as the vessel showed signs of approaching him in its gradual revolution among them" (59). The pun on revolution signals the political potential implicit in the lives of the laborers.

While Hardy pays attention to the making of capitalism in "the web of life" (Moore 2015, passim), he also considers economic acts that do not conform to that system. At times, the novel depicts labor without locating it in a capitalist matrix of wages and class stratification. The utopian potential embedded in labor surfaces in the novel's closure. Gabriel and Bathsheba bond through work, "their romance growing up in the interstices of a mass of hard prosaic reality": "This good-fellowship - camaraderie usually occurring through similarity of pursuits, is unfortunately seldom superadded to love between the sexes, because men and women associate, not in their labours, but in their pleasures merely" (383-384). Laboring as they do on the night of the storm is what brings the couple together and creates a horizontal relationship, countering their roles as employer and employee. Labor here is the gateway to an egalitarian interpersonal connection, although at the same time it is geared toward profit.

The kind of labor that is rooted in and cultivates mutual care marks the activities of shepherding. Where the sounds of farming intermix with those of nonhuman life, human and nonhuman labor converge toward a single goal:

Beyond [the meadow] the ground was melodious with ripples, and the sky with larks; the low bleating of the flock mingling with both. Mistress and man were engaged in the operation of making a lamb 'take,' which is performed whenever an ewe has lost her offspring, one of the twins of another ewe being given her as a substitute. (123)

If it seems easy to categorize the ripples or the larks as either elements of culture or nature, by the time we arrive at the ewes that are taking, the task is impossible. The sheep's adoption of another's offspring is possible only by human design. This adoption is a process through which humans and nonhumans together make their environments, as the mother sheep are agents in the adoption process as well as humans. Conjuring a realm of care that is not exploitative, the cross-species work of adoption here gestures beyond capitalist relations, ${ }^{9}$ even though the stratification in "mistress and man" challenges that gesture. The historicity of the novel's ecological vision does not prevent fleeting glimpses of alternatives to market relations.

By embedding capitalist relations in the web of life, Hardy counters the kind of abstraction that Boldwood undertakes when he idealizes Bathsheba. Such historicization is oppositional to the abstractions performed by capitalism and its law of value. The complex, multi-layered temporality ascribed to shepherding and farming in this pastoral ensures that capitalist practices are not reified. This negative correlation between a dynamic temporality and abstraction resonates with Devin Griffiths and Deanna K. Kreisel's call for an open-ended ecology: "In thinking ecology as an active system rather than a stable thing, we simply consider critically those strategies of formalization, abstraction, and simplification that arrest change. In energetic terms, abstraction performs a cooling down or congealing 
of ideas, institutions, and fields" $(2020,10)$. To critique abstraction in its multiple forms is to enable a fuller view of ecological relations in their historical specificity. The pastoral mode as it is realized in Far from the Madding Crowd historicizes ecology by highlighting contingency and introducing a spectrum of temporalities.

\section{Notes}

1. W. W. Greg singles out the contrast between "pastoral life and some more complex type of civilization" as the defining characteristic of the mode in 1906 (4).

2. Hardy's The Woodlanders (1886-1887), of course, also evinces the pastoral's ability to attend to economic hardship, specifically dispossession.

3. In an alternative strand of recent criticism, the pastoral seems irreconcilable with economic activity. Stephan Regan writes, "If Under the Greenwood Tree and Far from the Madding Crowd initially present themselves as pastoral romances, what they ultimately reveal is that love and marriage are not simply matters of the heart, but choices and decisions involving complicated economic and cultural factors" (2009, 252-253).

4. Dialectically, another mode of concrete time also emerges under capitalism, but it is distinct from seasonal time, according to Moishe Postone (Harootunian et al. 2012, 11).

5. Following Caroline Levine, I use the term affordance to evoke a capacity inherent in form $(2015,6)$.

6. Elizabeth Carolyn Miller offers the insight that Hardy's fiction involves "the material specificity of the ecological" $(2016,702)$.

7. Despite the novel's meticulous accounts of debt, wage labor, and the marketplace, earlier criticism has approached the farming activities of Weatherbury as timeless, as if the residents were still part of a feudal economy (see Squires 1974, 126).

8. Hardy appears to have thought that the liberal economic approach to human life was problematic for its lack of altruism. In a marginal note that he recorded in a volume by the political economist John Ramsay McCulloch, he commented that a purely economic approach "to improve our condition" was not enough and that we should also consider "that of others" (Millgate 2004, 88-89).

9. My reading of this scene is informed by Kreilkamp's assertion that "in the culture of the sheep-fold" "we are ... in a realm of neither the purely human nor the natural" (476).

\section{Disclosure statement}

No potential conflict of interest was reported by the author(s).

\section{Notes on contributor}

Ayşe Çelikkol is Assistant Professor in the Department of English Language and Literature at Bilkent University in Ankara, Turkey. She is the author of Romances of Free Trade: British Literature, Laissez-Faire, and the Global Nineteenth Century (New York: Oxford University Press, 2011). Her essays on nineteenth-century British and American literature have appeared in journals such as ELH, American Literature, Victorian Poetry, and the Journal of Victorian Culture. Her recent work explores links between ecology and capitalism in Victorian literature.

\section{References}

Alpers, Paul. 2011. What Is Pastoral? Chicago and London: University of Chicago Press.

Bate, Jonathan. 2013. Romantic Ecology: William Wordsworth and the Environmental Tradition. London: Routledge. 
Beer, Gillian. 2000. Darwin's Plots: Evolutionary Narrative in Darwin, George Eliot, and NineteenthCentury Fiction. Cambridge: Cambridge University Press.

Bryer, Rob. 2004. "The Roots of Modern Capitalism: A Marxist Accounting History of the Origins and Consequences of Capitalist Landlords in England." The Accounting Historians Journal 31 (1): 1-56.

Burkett, Paul. 2003. "The Value Problem in Ecological Economics: Lessons From the Physiocrats and Marx." Organization and Environment 16 (2): 137-167.

Chakrabarty, Dipesh. 2009. “The Climate of History: Four Theses.” Critical Inquiry 35 (2): 197-222. Clark, Indy. 2015. Thomas Hardy's Pastoral: An Unkindly May. New York: Palgrave Macmillan.

Çelikkol, Ayşe. 2020. "World Ecology in Martineau's and Gaskell's Colonial Pastorals." Journal of Victorian Culture 25 (1): 110-125.

Goode, John. 1990. "Hardy and Marxism." In Critical Essays on Thomas Hardy: The Novels, edited by Dale Kramer with Nancy Marck, 21-38. Boston: G. K. Hall and Company.

Greg, Walter W. 1906. Pastoral Poetry and Pastoral Drama. London: A. H. Bullen.

Griffiths, Devin, and Deanna Kreisel. 2020. "Introduction: Open Ecologies." Special issue. Open Ecologies ed. Devin Griffiths and Deanna Kreisel. Victorian Literature and Culture 48 (1): 1-28.

Hardy, Florence Emily. 1962. The Life of Thomas Hardy. New York: St Martin's Press.

Hardy, Thomas. 2002. Far From the Madding Crowd. Oxford: Oxford University Press.

Harootunian, Harry, Moishe Postone, Joyce Liu, Viren Murthy, Chih-ming Wang, and Ming Tu. 2012. "Exigency of Time: A Conversation with Harry Harootunian and Moishe Postone." Concentric 38: 7-43.

Harvey, David. 1982. The Limits to Capital. Oxford: Blackwell.

Hensley, Nathan, and Philip Steer. 2018. Ecological Form: System and Aesthetics in the Age of Empire. New York: Fordham University Press.

Horace. 1907. Odes and Epodes of Horace. Translated by John Marshall. London: J. M. Dent.

Kettle, Arnold. 2016. An Introduction to the English Novel. Vol 2. New York: Routledge.

Kreilkamp, Ivan. 2009. "Pitying the Sheep in Far From the Madding Crowd." Novel: A Forum on Fiction 42 (3): 474-481.

Levine, Caroline. 2015. Forms: Whole, Rhythm, Hierarchy, Network. Princeton: Princeton University Press.

Lindenbaum, Peter. 1986. Changing Landscapes: Anti-Pastoral Sentiment in the English Renaissance. Athens: University of Georgia Press.

Lindenberger, Herbert. 1972. “The Idyllic Moment: On Pastoral Romanticism.” College English 34 (3): 335-351.

MacCaffrey, Isabel G. 1969. “Allegory and Pastoral in The Shepheardes Calender.” ELH 36 (1): 88109.

Martell, Jessica. 2013. "The Dorset Dairy, the Pastoral, and Thomas Hardy's Tess of the D'Urbervilles." Nineteenth-Century Literature 68 (1): 64-89.

Marx, Leo. 1964. The Machine in the Garden: Technology and the Pastoral Ideal in America. New York: Oxford University Press.

Marx, Karl. 1967. Capital. New York: International Publishers.

Marx, Karl. 1975. Theories of Surplus Value. Translated by Emile Burns. Vol 1. Moscow: Progress Publishers.

Marx, Karl. 1976. Value: Studies by Karl Marx. Translated and edited by Albert Dragstedt. London: New Park Publications.

Meiksins Wood, Ellen. 2008. "Historical Materialism in 'Forms Which Precede Capitalist Production'.” In Karl Marx's Grundrisse: Foundations of the Critique of Political Economy 150 Years Later, edited by Marcello Musto, 79-92. Oxford and New York: Routledge.

Miller, Elizabeth Carolyn. 2016. "Dendrography and Ecological Realism." Victorian Studies 58 (4): 696-718.

Millgate, Michael. 2004. Thomas Hardy: A Biography Revisited. New York: Oxford University Press.

Moore, Jason W. 2015. Capitalism in the Web of Life: Ecology and the Accumulation of Capital. London and New York: Verso. 
Nemesvari, Richard. 2007. “'Genres are not to be Mixed ... . I Will Not Mix Them': Discourse, Ideology, and Generic Hybridity in Hardy's Fiction." In A Companion to Thomas Hardy, edited by Keith Wilson, 102-116. Malden: Wiley-Blackwell.

O'Gorman, Francis. 2013. “Thomas Hardy and Realism.” In Thomas Hardy in Context, edited by Phillip Mallett, 113-121. Cambridge: Cambridge University Press.

Patterson, Annabel. 1987. Pastoral and Ideology: Virgil to Valéry. Berkeley and Los Angeles: University of California Press.

Pite, Ralph. 2009. “'His Country”: Hardy in the Rural.” In A Companion to Thomas Hardy, edited by Keith Wilson, 133-145. Malden: Blackwell.

Puttenham, George. 1869. The Arte of English Poesie. London: A. Murray.

Regan, Stephen. 2009. "The Darkening Pastoral: Under the Greenwood Tree and Far From the Madding Crowd." In A Companion to Thomas Hardy, edited by Keith Wilson, 241-253. Malden: Blackwell.

Shaw-Taylor, Leigh. 2011. "The Rise of Agrarian Capitalism and the Decline of Family Farming in England.” Economic History Review 65 (1): 26-60.

Smith, Adam. 1887. An Inquiry Into the Nature and Causes of the Wealth of Nations. Edinburgh and New York: T. Nelson and Sons.

Smith, Neil. 1984. Uneven Development: Nature, Capital, and the Production of Space. New York: Basil Blackwell.

Squires, Michael. 1974. The Pastoral Novel: Studies in George Eliot, Thomas Hardy, and D. H. Lawrence. Charlottesville: University Press of Virginia.

Virgil. 2012. Virgil's Eclogues. Translated by Len Krisak. Philadelphia: University of Pennsylvania Press.

Williams, Raymond. 1970. The English Novel From Dickens to Lawrence. New York: Oxford University Press.

Williams, Raymond. 1975. The Country and the City. New York: Oxford University Press. 